\title{
THE HAGUE PEACE SYSTEM IN OPERATION ${ }^{1}$
}

By' James L. Tryon, Secretary of the Massachusetts Pcace Society

When the First Hague Conference adjourned, it left the signatory powers with a set of machinery for the prevention of war. The conference was not an assembly of visionaries nor of doctrinaires. but of practical men who worked on an historical basis. It adopted as international law only stuch principles as had previously been recognized, or were in process of recognition, by the nations. It sanctioned, for the most part, only such preventive measures as had been proved to be, or were believed to be, feasible. These were mediation, the international commission . of inquiry, and arbitration.

To go back no farther than 1794 , international arbitration had behind it about a century of history." Mediation, though formerly identified with interference and, therefore, out of favor, had in recent years been effective in stopping wars, and the Conference thought it could prevent them. ${ }^{3}$ The international commission of inquiry, although apparently an innovation, was not really so: International commissions had surveyed and adjusted boundary lines. The United States had gone so far in 1896 as to appoint a national commission of examination into the merits of a controversy between Venezuela and Great Britain over the British-Guiana boundary.* It had also, in I898, like Spain, appointed a board of naval officers to ascertain the cause of the explosion of the battleship Maine in Havana Harbor. Had an international commission been appointed in the latter case, with access to all the facts that both Spain and the United States could have furnished in a joint effort to get at the truth, it is possible that the result might have been different, although no reflection is cast upon the spirit of the boards appointed, the conclusions of which were contradictory, one assigning as the cause of the

1 All rights reserved.

"Darby's "International Tribunals," $769-9 \mathrm{co}$. Instances of international arbitration. Moore's International Arbitrations; 6 volumes. Trueblood's Arbitration at the Opening of the Twentieth Century.

${ }^{3}$ Holls; I8O-I8I.

* For discussion of the use and theory of commissions: Holls; 203220. 
wreck an external and the other an internal explosion. The Hague Conference did not, however, set up a standing board of inquiry. It simply proposed a method to be utilized in case of emergency.

The untried feature of the system of mediation that was adopted was that of seconding powers which should have charge, for a time, of the affairs of two nations that were embroiled in a controversy, and try to effect peace. Mr. Holls, who proposed this measure, believed that it would have been efficacious in stopping the war between the United States and Spain. "After the battle of Manila, and surely after the battle of Santiago," he says, "the seconds could have convinced Spain that further struggle was hopeless and that her honor (which in this case was the point in isste for her) had been amply vindicated." "

The uniqueness of the scheme for arbitration was the international court, or panel, of judges from which a tribunal might be chosen. This could be used as a substitute for mixed commissions or for sovereigns acting as arbitrators, according to the practice of the Igth century, but it did not entirely displace them; for, with plenty of caution against rashness, the convention also provided that a special tribunal might be created, other than from the panel of the court, or that a sovereign might act as arbitrator. The tribunal chosen to try a particular case might be constituted so as to include members of the panel who were the appointees or the nationals of the contending nations. The old way and the new way were both recognized and nations were allowed to take whichever they chose. This surely meant progress by evolution rather than revolution, and was not a leap in the dark.

Of the three methods proposed for the prevention of war, none of them was compulsory. The nations might resort to them or not as they should see fit. The court had no other sanction to enforce obedience to its decisions than public opinion and the good faith of the litigant nations, which were, then, and are. even now, regarded in some quarters as insufficient. Arbitration was the only method that was legal in its nature; the international commission of inquiry was moral; mediation was diplomatic.

¿E. J. Benton's "International Law and Diplomacy of the SpanisliAmerican $I$ War;" $76-77$, for a brief statement with references. Also 6 Moore: International Law Digest, I8I-I84.

"Holls, before the Mohonk arbitration conference, Mohonk Report, 1900, 14 . 
The mediator could not compel, he could only recommend peace. His function ceased when his overtures were rejected, but these, by agreement, were never to be regarded as unfriendly acts. Both mediation and the international commission of inquiry, however, were seen to be valuable adjuncts to an arbitral system. The employment of either in the settlement of international disputes might result in an arbitration. The international commission of inquiry was restricted to the elucidation of facts. It was not to fix blame; it could not pronounce a decision having the effect of an arbitral award; from its jurisdiction questions of national honor and vital interest could be excluded; but it was a means of referring to steady minds a question that, if left to the passionate discussion of people in possession of but half the facts, or to designing politicians tempted to pervert them, might result in war. Recourse to it was like saying to the world: "Suspend all judgment until you hear the report of the commission." The mèasure was well calculated to prevent precipitous action.

The Convention for the Pacific Settlement of International Disputes, although it was intended to be progressive, had about it: such possibilities of evasion and of failure that one might have asked, and the world did ask, "Will this system work?" A few years of trial have silenced many of the doubts of skeptics and more than justified the expectations of those who believed that the plan would succeed. Mediation stopped the war between Russia and Japan, one of the greatest wars of modern times. The international commission of inquiry probably prevented another war from breaking out at the same time between Russia and Great Britain. The several cases tried by the Hague Court, whatever evils they may have prevented, have settled issues that diplomatists could not adjust to satisfaction. and which, in one case, the Fisheries, had baffled the efforts of the wisest statesmen in England and America for nearly a hundred years.

The system has been so successful that it has won the confidence of the world, but it must and will be improved, in the light of experience, by succeeding Hague Conferences until it is brought to perfection. In this work, every American publicist and lawyer ought to have his honorable share. For the present, it is interesting to observe how and to what extent the system, when put to trial, has actually worked. 


\section{GOOD OFFICES OR MIEDIATION.}

Since the Hague Conferences have been held, and the Convention for the Pacific Settlement of International Disputes has been in effect, there have been no noteworthy cases in which good offices and mediation have prevented a war, if we except the case of Argentine and Chile who, when war threatened, were persuaded, to some extent by Great Britain, but also by noble national leaders, to settle their boundary dispute by arbitration, ${ }^{7}$ or the peace of thellarblehcad, an incident in which the Lnited States and Mexican governmients arranged, on a United States warship, a peaceful understanding between three Central American powers. ${ }^{8}$ None of the parties about to engage in war were, however, at the time signatories to the First Hague Conference. Preventive mediation is still a matter of future development, but progress is being made with it, especially by the United States in Latin-America, in cases that are not known to the world at large."

The most important of the recent cases of the use of good offices and mediation among South American states has occurred within a year in connection with a controversy between Peru and Ecuador in regard to the ownership of a large area of land in the valley of the Amazon. War threatened when the L'nited States, assisted by the governments of the Argentine Republic and Brazil. used their influence and brought about peace. All the parties concerned, mediators and contestants, are signatories to the Hague Conventions for the Pacific Settlement of International Disputes, which fact in this case was used to advantage.

The United States government was asked by the Boers to tender its good offices in bringing to a close the South African war, but its overtures were declined by Great Britain. The best

iFor a brief story of the threatened war hetween Argentine and Chile, see "The Christ of the Andes"; American Peace Society, roro. For additional information on the arbitration, see Colonel Sir Thomas Hungerford Holdich: The Countries of the King's Aatard. The award of King Edward, the arbitrator, was made in 1902. For further references, see Darby, 9r.

s Amcrican Journal of International Laa', $1: 14 \mathrm{I}$.

"For recent efforts of the United States government to preserve peace among Latin-American countries by use of its good offices, see speech by Honorable Darid J. Foster, late Chairman of the House Committee on Foreign Affairs: Congressional Record. 62 Congress. first session, 4.493. 
illustration, however, of the successful use of good offices to stop a war, since the Hague Conference has been established, and perhaps the best in all modern history, is that afforded by the example of President Roosevelt, who, at an opportune moment, came as a mediating friend between Russia and Japan. If the mediatory methods suggested by the Hague Conferences had nothing else to recommend them to those who are asked to believe in the possibility of preventive mediation than this instance alone, they would still hold out encouragement to humanity to have faith in their final utility. President Roosevelt's famous message addressed to the ministers of the United States at St. Petersburg and Tokyo, dated June 8th, 1905, reads:

The President feels that the time has come when in the interest of all mankind he must endeavor to see if it is not possible to bring to an end the terrible and lamentable conflict now being waged. With both Russia and Japan the United States has inherited ties of friendship and good will. It hopes for the prosperity and welfare of each, and it feels that the progress of the world is set back by the war between these two great nations.

The President accordingly urges the Russian and Japanese Governments, not only for their own sakes, but in the interest of the whole civilized world, to open direct negotiations for peace with one another. The President suggests that these peace negotiations be conducted directly and exclusively between the belligerents; in other words, that there may be a meeting of Russian and Japanese plenipotentiaries or delegates without any intermediary, in order to see if it is not possible for these representatives of the two powers to agree to terms of peace. The President earnestly asks that the Russian (Japanese) Government do now agree to such meeting, and in asking the Japanese (Russian) Government likewise to agree.

While the President does not feel that any intermediary should be called in in respect to the peace negotiations themselves, he is entirely willing to do what he properly can, if the two powers concerned feel that his services will be of aid in arranging the preliminaries as to the time and place of meeting. But if even these preliminaries can be arranged directly between the two powers, or in any other way, the President will be glad, as his sole purpose is to bring about a meeting which the whole civilized world will pray may result in peace.

This communication led, in due time, to an agreement between Russia and Japan to appoint plenipotentiaries. As will be remembered, they signed at Portsmouth, N. H., August 23d, Sep- 
tember 5th, 1905, a treaty of peace, called the treaty of Portsmouth. ${ }^{10}$

\section{THE INTERNATIONAL COMAISSION OF INQLIRY.}

The general principles of the international commission of inquiry are contained in Article 9 on this subject, in the Hague Convention of 1907 , which is substantially the same as that adopted in 1899 . The article says:

In differences of an international nature involving neither honor nor vital interests, and arising from a difference of opinion on points of fact, the contracting powers deem it expedient and desirable that the parties who have not been able to come to an agreement by means of diplomacy, should, as far as circumstances allow, institute an international commission of inquiry, to facilitate a solution of these disputes by elucidating the facts by means of an impartial and conscientious investigation.

The working of this measure may be clearly seen in the history of the North Sea incident.

During the Russo-Japanese War, the Russian Baltic fleet was coaling off the coast of Norway, preparatory to going to the Far East to participate in the war with Japan. News came (October 20 , 1904) to the Russian Admiral in command that Japanese torpedo boats had been seen in the vicinity. The admiral took alarm. He ordered his fleet to sea twenty-four hours before the expected time of its departure. It proceeded in several divisions. As the leading division was passing through the North Sea in the night, it passed a fleet of fishing boats, about fifty in number, afterwards proved to be the Hull fishing fleet of England. As the innocent character of the boats was evident and no Japanese was seen among them, the warships passed on. The second division had a similar experience, but, when the last division, which was in charge of the admiral himself, came along, the circumstances, combined with the nervous alarm of the Russians, were such as to cause deception.

It happened that one of the Russian transports had fallen about fifty miles behind its companions, in consequence of defective

${ }^{10} 7$ Moore: International Law Digest; see generally sections 10651067. Hishida: International Position of Japan as a Great Pozier, 239274. Hershey: International Law and Diplomacy of the Russo-IapaneseIVar, 346-359. 
rengines. The officers of that transport, on the lookout for Japanese torpedo boats, had seen a strange vessel approaching at about eight o'clock in the evening (October 2I), and, under an impulse of desperation due to their sense of isolation and small armament, fired upon it. They, then, without further investigation, sent a wireless message to the admiral, saying: "Attacked on all sides by torpedo boats." The rumor that the Japanese were at hand was now confirmed in the admiral's mind. He made a calculation. His fleet was sailing at the rate of from ten to twelve miles an hour. The torpedo boats, capable of much greater speed, might overtake him and perhaps destroy his vessels in five hours. He gave orders that, if the attack should come from the front, the officer on watch should fire upon the Japanese without consulting him, but, if the attack were made from the rear, he desired to be notified. In any event, should an attack occur, whatever vessels were revealed by the search-lights of his flag-ship, should be the commander of the fishing fleet sent up a green rocket which meant "trawl on the starboard tack." The officer on watch on the admiral's flag-ship who was scanning the seas for Japanese torpedo boats, became suspicious. He called his comrades, and their suspicions were increased as they looked through their night glasses at a mysterious object in the distance. They turned on the search-light, and there seemed to be approaching the ship, on the starboard side at a great rate of speed, only eighteen or twenty cable lengths distant, a Japanese torpedo boat. The firing began by the admiral's command. A moment later, a fishing boat was seen near the bow of the ship. This fact being reported to the admiral, he gave orders to turn up the search-lights at an angle of forty-five degrees, so that the boat might not be seen, and signaled his vessels not to fire upon trawlers. Meantime, however, suspicion was attracted to the port side of the battleship and the search-lights revealed in that direction what appeared to be another Japanese torpedo boat. Firing began on that side. The search-lights were no longer confined to the admiral's ship, but were used by the other vessels of the fleet in order to avoid surprise. Great confusion followed, during which some of the Russian shots struck Russian war vessels and only strengthened previous suspicions. But the whole affair was a mistake. No Japanese torpedo boats were in the North Sea or in that neighborhood, thousands of miles from home, and the fire of the Russian fleet had fallen upon innocent fishermen. As a result of it, two 
fishermen were killed, and six others injured; one trawler was sunk, five others suffered damage by being hit, and others were injured by the explosion of shells near them. The Russians, still laboring under misapprehension, did not stop to make further investigations or offer relief, but continued on their course, grateful to have escaped with slight injuries. The Russian admiral would have been wise had he notified some of the powers of the episode, as he passed through the British Channel, and suggested that possibly fishermen who were near the scene of the skirmish might need assistance, but he did not do this, nor did he make any report until he was called upon to do so by his government, some days later.

When the news of this disaster, which was brought by the aggrieved fishermen, came to England, the people were aflame with excitement. The Russian officials at the British embassy and at St. Petersburg, still uninformed as to the facts, could offer no explanation. For a week or more, the British cabinet ministers were obliged to appease the anger of their people as best they could, and seek as satisfactory a statement as they could get from the Russian Foreign Office. The British Government made the following demands:

That the explanation from Russia should consist of " (I) an ample apology and disclaimer, (2) the fullest reparation to the sufferers, (3) a searching inquiry as to blame, together with the adequate punishment of any persons shown to be responsible, and (4) security against the repetition of such incidents. As to the first two points, the message of the Emperor afforded an assurance that there would be no difficulty; but as to the other demands, no agreement was as yet in sight, and it was as to these, and especially the question of punishment of wrongdoers, that public feeling in England was running high."

In order to support its position, the British Government gave orders for the concentration of the British fleet at Gibraltar and other points to intercept the Russian fleet should war be necessary, and it hinted that unless the Russian fleet should call at Vigo, in Spain, to leave officers to make a report on the incident, the two governments might find themselves at war before the week was over.

The correspondence continued, and, meantime, France, in a lindly way, exercising her friendly offices, suggested resort to an international commission of inquiry. The appropriateness of 
referring the question to such a commission had appealed strongly both to the British Gorernment and to the Czar. An agreement was soon reached in the matter. An international commission was formed consisting of admirals from the British, Russian, United States, French, and Austrian navies, which met at Paris, and, after going over the case carefully, made a report in February, I905. This commission found that the Russian admiral, though there could be no reflection upon his humanity or military qualifications, was, nevertheless, responsible for the firing upon the fishermen. Russia accepted the decision and paid damages to the extent of about $\$ 300,000$. This settlement was final and there was no war.

What would have happened had there been war in this case, nobody can say, although most people would probably speculate that, as Russia was at war at the time with Japan, and her army and navy in poor condition, England would have won, but there might have been a long struggle that would have caused the loss of thousands of lives by battle and by disease and might have cost, in money and the destruction of property, hundreds of millions of dollars, to pay which the people of Great Britain and Russia might have been taxed for years. ${ }^{\circ}$ As the affair turned out, only two men were killed and a few others wounded; only one ship was sunk and a few others injured. The money cost was only about $\$ 300,000$. This solution shows the advantage of settling international difficulties on the basis of reason and justice instead of the basis of passion and force, and it has established the success of the international commission of inquiry as a part of our machinery for the preservation of international peace. The case further shows that questions of honor and vital interest can be taken up by an international commission of inquiry with safety to the parties concerned.11

Of this incident, Professor Moore said, at the Mohonk Arbitration Conference of 1905 :

A day or two ago the question was discussed here as to the desirableness or necessity of excluding from arbitration questions of national honor or questions of vital interest; but I venture to

${ }^{11}$ John Bassett Moore: Mohonk Arbitration Conference Report, I905, I43. Hershey: International Laze and Diplomacy of the Russo-Japanese War, 21\%. Higgins: The Hague Pcace Conferences, 167-170. 2 American Journal of International Law, 929, for the finding of the international commission of inquiry. 
say that in this North Sea incident there were involved both questions of national honor and questions of vital interest. Surely nothing can more affect the honor or the interests of a government than the wrongful taking of the lives of its people, especially where they are assailed at the hands of the officials of a foreign power. Not only is the arbitral settlement of the North Sea incident a proof of the growth in the world of a magnanimous and enlightened spirit, but it is to be placed among the great cases in which that mode of settlement has brought peace, with honor, to the lasting benefit of the powers immediately concerned and to the great advantage of the whole world..$^{12}$

The procedure developed by this international commission of inquiry was reported to the Second Hague Conference, and was, in substance, adopted by it as a suggestion for future use in similar cases.

\section{THE HAGUE COURT. ${ }^{13}$}

For some time after the permanent court was created and its panel of judges appointed, there was a feeling that it might never be used. One of the reasons why provision was not made for the

12. Mohonk Arbitration Report, 1905, 150.

13 THE HAGUE COURT CASES.

(1) The Pious Fund Case. United States of America $v$ the United Mexican States. Protocol signed at Washington, May 22, 1902. Decision at The Hague, October I4, 1902. Arbitrators designated by the President of the United States-Sir Edward Fry (Great Britain), and Dr. F. De Martens (Russia) ; designated by the President of Mexico-Dr. T. M. C. Asser (Netherlands), and Dr. J. A. F. de Savornin Lohman (Netherlands), who met and chose as umpire and president, Dr. Henning Matzen (Denmark). $2 \mathrm{Am}$. Jour. Int. Laz', 893. See a readable and informing account of this case by Hon. William L. Penfield: The Hague Court in the Pious Fund Arbitration, Ifohonk Arbitration Report, 1903, 83. See for a discussion of the first two cases and of proposed improvements in the court, John IV. Foster: Arbitration and the Hague Court, chapters 5 and 6. Cf. also J. H. Ralston: Some Suggestions as to the Permanent Conrt of Arbitration in I Am. Jour. Int. Laze, 32I. Penfield again on International Courts of Justice: Penn. Arb. and Peace Conf. Report, I908, 59. United States 'ss. Mexico-Report of Jackson H. Ralston, Agent of the United States and of Counsel, in the matter of the Pious Fund of the Californias, published as Senate Document No. 28, 57th Congress, and Session.

(2) The Venezuela Preferential Payment Case. Germany, Great Britain, and Italy $\sigma$. Yenesucla et als. Protocols signed at Washington, Feb. I3, I903, and May 7, I903. Decision at The Hague, Feb. 22, I904. Arbitrators named by the Czar of Russia at the request of the interested 
court to go into regular annual session was a fear entertained by the nembers of the First Hague Conference that, if it should hold sessions, but have no cases, it would be discredited in the pullic estimation as a farce. The court, however, was destined to live and not to die. It was given its first case through the influence of President Roosevelt. This is known as the Pious Fund Case.

The trial of this case showed how the new institution worked. The case has a history. In the latter part of the seventeenth and early part of the eighteenth century, some good people of Spain gave in trust to the Society of Jesus about $\$ 1,700,000$ for the conversion of heathen in California. When the Jesuit order was excluded from Spain ( 1767 ), and suppressed by the Pope

powers-Mr. N. V. Mouravieff (Russia), Dr. H. Lammasch (AustriaHungary), and Dr. F. de Martens (Russia). Mr. Mouravieff elected president. 2 Am. Jour. Int. Law, 902. See address by Hon. William L. Penfield, Mohawk Arbitration Report, I9O4, 35.

(3) The Japanese House Tax Case. Great Britain, France, and Germany a. Japan. Protocol signed at Tokyo, August 28, 1902. Decision at The Hague, May 22, 1905. Arbitrators designated by the governments of Germany, France, and Great Britain-Professor Louis Renault (France), by the government of Japan-Dr. Itchiro Motono; who elected as umpire Mr. Gregers Gram of Norway. 2 Am. Jour. Int. Law, 9it.

(4) The Muscat Dhows Case. Great Britain a. France. Protocol signed at London, October 13, Ig04. Decision at The Hague, August 8, 1905. Arbitrators designated by the government of Great Britain-Hon. Melville W. Fuller (United States); by the government of France-Dr. J. A. F. De Savornin Lohman (Netherlands). Professor H. Lammasch was, by agreement, chosen umpire by the King of I taly, the arbitrators having failed within a month to choose an umpire themselves. $2 . A m$. Jour. Int. Law, 92I.

(5) The Casablanca Case. France i. Germany. Protocols signed November ro and 24, 1908. Decision at The Hague, May 22, 1909. Arbitrators designated by the government of the French Republic-Sir Edward Fry (Great Britain), and Professor Louis Renault (France); by the Imperial German government, Dr. Guido Fusinato (Italy) ; Dr. Kriege (Germany), who met and chose as umpire Dr. K. Hj. L. de Hammarskjold (Sweden). 3 Am. Journ. Int. Law, 755.

(6) The Maritime Boundary Case. Norway z. Szedcu. Convention, March 14, 1908. Decision at The Hague, October 23, 1909. Arbitrators and umpire designated by the governments-Dr. J. A. Loeff (Netherlands), president; Mr. F. V. N. Beichmann (Norway); Dr. K. Hj. I. de Hammarskjold (Sweden). 4 Am. Jour. Int. Laze, 226.

(7) The North Atlantic Coast Fisheries Case. United States of America v. Great Britain. Protocol signed at Washington January 27, 1909. Decision at The Hague September 7, rgro. Arbitrators designated by the United States-Hon. George Gray (United States), and Dr. Luis 
(1773), the Spanish Govermment took over the fund and administered it for the donors. Later, when the government of Mexico was established, it succeeded to the fund, merged it with other national funds, and paid a regular annuity on it to the Catholic Church authorities in California. After the cession of California to the United States at the close of the Mexican War, the American Catholic authorities in California claimed the annuities enjoyed by their predecessors. Being unable to get them, they appealed to the United States Government for its intervention. The matter of the claim was referred, in 1869 , to a mixed commission appointed to settle cross claims between the two countries. The commissioners disagreed as to the claim which was then referred to Sir Edward Thornton as umpire,

MI. Drago (Argentine Republic; by Great Britain, Dr. J. A. F. De Savornin Lohman (Netherlands), Sir Charles Fitzpatrick (Canada), who met and chose Prof. Lammasch (Austria-Hungary) as president. 3 Am. Jour. Int. Law, Supplement, I68, for special agreement. 4 Am. Jour. Int. Law, 948 , for decision. One of the most helpful articles on this case is that of Robert Lansing, The North Atlantic Fisheries Arbitration, in $5 \mathrm{Am}$. Jour. Int. Law, I, to which the writer is specially indebted.

(8) The Orinoco Steamship Company Case. The United States $v$ I"enezuela. Protocol signed at Caracas February 13, 1909. Decision at The Hague, October 25, 1910. Arbitrators designated by the United States - His Excellency, M. Gonzalo de Queseda y Arostegui (Cuba); by Venezuela-His Excellency, A. Beernaert (Belgium), who met and chose Prof. H. Lammasch, as president. 3 Am. Jour. Int. Law, supplement 224, for protecol. $5 \mathrm{Am}$. Jour. Int. Laz, 230, for decision. See also address of Dr. Lammascl upon the opening of the tribunal, $5 \mathrm{Am}$. Jour. Int. Law, 32, and a valuable historical and legal article, with a discussion of the developments in the procedure of the court, by Hon. William Cullen Dennis. The Orinoco Steamship Case before the Hague Tribunal, the same, 35 .

(9) The Savarkar Case. France v. Great Britain. Protocol signed at London, October 25, I9ro. Decision at The Hague, February 24, 191x. Arbitrators designated by the governments, one of whom should be a national of each, Mr. A. Beernaert (Belgium), president; the Earl of Desart (Great Britain); Prof. Louis Renault (France); Mr. Gregers Gram (Norway); Dr. J. A. F. De Savornin Lohman (Netherlands). 5 Am. Jour. Int. Law, supplement, 37, for protocol. 5 Am. Jour. Int. Laz, 520 , for decision. An editorial on this case will be found in $5 \mathrm{Am}$. Jour. Int. Law', 208 .

In general, for introductory matter on the Hague Court cases, see the Amcrican Journal of International Lai', and the Advocate of Peace. The New York Independent and the Outlook have frequently printed editorials, or other articles, by leading writers of the day on international disputes as they have arisen, or in connection with the decisions of the Hague Court. For full details, see Government Reports. 
who in 1875 awarded to the Lnited States Government twentyone annuities of $\$ 43,050.99$ each up to 1869 . The Mexican Government paid the award, but declared that it constituted a final settlement. The church authorities, on the other hand, maintained that the annuities should continue and again asked the assistance of the United States Government to secure them. Correspondence between the Mexican and the American Governments resulted in disagreement. It was at this point, on March 13, I902, while the Hague Court was lying idle, that President Roosevelt suggested, through Secretary Hay and Ambassador Clayton to the Mexican Government, that the two greatest American republics ought to have the honor of giving the Hague Court its first case, and should avail themselves of the opportunity open to them before any other nations should take advantage of it. The suggestion was adopted. A tribunal was chosen from the Hague panel, none of whose members was, however, a subject of the litigating states.

The question was put to the tribunal whether the claim of the United States, based on Sir Edward Thornton's award, was within the governing principle of res judicata, and, if not whether it was just; the tribunal to render a just and equitable award. The arguments were duly presented before the court at the Hague and, in a short time, a decision was made that the award was governed by the principle of res judicata, as contended by the United States, and Mexico was held responsible for a contintrance of the annuities. The United Mexican States were ordered to pay to the United States of America $\$ 1,420,682.67$ in accumulated annuities, and $\$ 43,050.99$, perpetually, on the second day of February, in Mexican legal currency. The decision of the Hague Court settled the differences to the satisfaction of both parties to the controversy. It reaffirmed res judicata as a principle of international law, but, more than that, established the international court in the public confidence.

The case is also interesting from the fact that it throws light upon the procedure used before the Hague Court. Mr. Penfield, counsel for the United States, speaking of this at the Mohonk Conference of 1903 (Rejort, p. 87), observed:

That the issues submitted by the arbitrating states to the Hague Court were joined and tried in essentially the same manner as the issues in law-suits before the municipal courts. 
There is, first, the transaction which begets the controversy. This results in conflicting contentions and arguments between the parties until the ultimate issues of law and fact are evolved and reduced to written form. Then the case is brought before the appointed court, to whom the statements of the case and the evidence on either side are submitted. On the hearing, the one having the affirmative opens and is followed by the adversary. The court holds stated sessions, decides incidental questions of procedure, finally declares the hearings closed, then deliberates and renders solemn judgment. In short, the principles of judicial procedure are essentially the same, whether before the Roman praetor, the civil courts of Germany, France, Italy, Spain or South America, or before the English or American judge or magistrate, or the supreme court of the state, or the supreme court of nations.

Two other cases soon came before the court which were of less significance, but tended to perpetuate it as a regular institution. One of these, the Japanese House Tax Case, was between Great Britain, France, and Germany on the one side, and Japan on the other. It was a question of taxation which related to the interpretation of treaties and other engagements by which these foreign governments held property under perpetual leases in the foreign concessions of Japan. The decision was rendered that, under the leases in question, not only were the lands, leased by foreigners in the concessions, but the buildings as well, exempted from taxation. In this case the Japanese arbitrator dissented.

Disputes having arisen between France and Great Britain over the extent to which the subjects of the Sultan of Mruscat might, under an agreement made March 10, I862, use the French flag on their vessels, and the nature and extent of other privileges granted, a case was made up for the court.

The decision defined the limits and conditions under which the Dhows were authorized to fly the French flag. As it had been alleged that the French flag was wrongly used to protect illegal trade in arms and slaves, serious trouble had been caused between the British and French goveruments, "which," says Dr. Darby (International Tribunals, page 906), "sometimes brought the two Powers within an ace of war."

Both cases showed that the court could successfully deal with the interpretation of treaties.

A more notable case than either of these was that known as the Venezuela Preferential Payment Case. Germany, Great 
Britain, and Italy held diplomatic claims against Venezuela for umpaid interest on public debts due their bond holders for money lent for building railways, other works of a public nature, special contracts, and on account of claims for injuries to their subjects during the disorders of revolutions. Germany proposed arbitration. Venezuela refused. Great Britain also proposed arbitration, but her offer was rejected. Italy wanted her claims adjusted, but was willing to accept the decision of a mixed commission. The offer was ignored. But it should be said that Venezuela insisted that her own laws were conclusive as to the matters in dispute.

Notice was given to the United States by Germany that it was her intention to blockade Venezuelan ports to enforce her -claims, but it was expressly stated that there was no intention of taking territory. The United States Government made no objection at the course of action determined upon, but refused to acquiesce when Germany, joined by Great Britain and Italy, established an anomalous pacific blockade. The form of the blockade was then changed from pacific to hostile, applied to all nations in the usual way, and was duly recognized by their attitude of neutrality. Within a day or two after the blockade began, Venezuela offered herself to arbitrate, but her belated courtesy was ignored. At this point, the government of Venezuela, assisted by the advice of her plenipotentiary, Herbert W. Bowen, agreed to assign, in payment of her debts to Germany, Great Britain and Italy, duties to the extent of thirty per cent from its customs receipts of La Guaira and Puerto Cabello, and made some payments to those powers.

Other powers who had claims against Veneztrela made peacefu1 demands for their share of payments. The question then arose whether the blockading powers should be given preference. The powers offered to refer the question to President Roosevelt, but he again proposed resort to the Hague Court. The case went to it and was decided in favor of the blockading powers, but the matter of the actual valtue of the respective claims of all the creditor powers was, by agreement, stubmitted to mixed commissions, consisting of one national each, of T'enezuela and the claimant nation, with a neutral as umpire, which met at Caracas and subsequently reported their awards.

Some question arose later as to the ethics of the decision. The statement was made that it put a premium on war-like 
methods instead of peaceful recourse to the law, but the critics of the court perhaps forgot that, in the present state of international law, a hostile blockade is a legitimate operation just as war itself is still legitimate, to which no protest was made by any of the interested peaceful powers before it was instituted, though notice of it had been given in advance. The judges in their decision took pains to point out this lack of protest by the non-blockading powers.

Professor Moore, at Lake Mohank, in commenting upon this decision (Report, 1904, p. 64), says:

In judicially deciding, therefore, that the blockading powers had by their forcible action acquired preferential position, which, but for their agreeing to submit the question to arbitration, they would have gone on to make effective, the Hague Tribunal merely declared and applied, as it was in duty bound to do, the existing international law. The Hague Tribunal is a judicial, not a legislative, body.

The moral aspect of this case was perhaps even more important than the legal. The fact was that three heavily armed powers had raised their hands and were about to strike a blow, when an agreement was reached by which it was possible to avoid serious hostilities by submitting the issue involved to the Hague Court. Not only that, but eleven nations, thirteen including Russia and Austria, who furnished the judges, representing about four hundred and fifty million people, committed themselves at one time to the use of the court for a peaceful settlement ínstead of war.

Speaking at a meeting of the American Society of Inter. national Law, when the imperfections of the Hague Court were under discussion, Mr. MacVeagh said of its decision in the Venezuelan Case, in which he was counsel:

That, while much can be said in criticism of the tribunal, and especially of the conduct of MIr. Mouravieff, who presided over it, and certainly much can be said as to the inaccuracy of its findings of fact as the basis for its decision, still, as I said then, when it was just over, and as I say now, such arbitration was of inestimable benefit to the peace of the world. Here were three great nations, with their war ships in the Caribbean Sea, blockading the ports of a weak South American republic, and that blockade was lifted when the arbitration was agreed upon, and those ships went home, never, I trust, again to cross the sea on such an errand. The selection of arbitrators happened to be unwise-two Russian diplomats and one Austrian diplomat were not likely to regard with favor the protest of Venezuela against 
the masterful conduct of Great Britain and Germany. But it was infinitely better for the world and its peace and its true prosperity that the question should be referred to such a tribunalnotwithstanding its mistakes of procedure, notwithstanding its mistakes in its findings of fact, notwithstanding its mistakes in its conclusions-infinitely better that it should be referred to the peaceful arbitrament of such a tribunal than that the United States should have been required, as she soon would have been required by the rising tide of indignation in the land, to order those fleets home. So I beg you to believe that among all the signs of a brighter day, among all the signs of the renaissance of the moral law, retaking its true place in the government of nations, no sign seems to me of better or brighter omen than the establishment of the court of arbitration at The Hague. With all its imperfections, with all its defects, it still stands there a signal to all peoples that here, in some halting, imperfect way, you can have a peaceful solution of your differences. ${ }^{14}$

A few years ago, it would have been thought a crazy notion of the peace advocates had anybody suggested that a dispute between France and Germany, on a sensitive point of honor, could be referred to a court of arbitration, but a tribunal at the Hague settled to satisfaction a remarkable case of this lkind in 1909. It is known as the Casablanca Incident.

Six soldiers from the French foreign legion in Morocco deserted, and secured by improper means a safe conduct home from the German consul. They were forcibly taken from his protection by French soldiers who arrested them September 25, 1908, having threatened and fired upon the native Moroccan guard who had the men in charge.

Diplomatic representatives of the two governments failing to come to a satisfactory understanding, the dispute was referrer! to the Hague Court. The tribunal partook somewhat of the character of an international commission of inquiry. It was empowrered to decide questions of law and fact, and anthorized to go, or send a delegate, to the scene of the incident in order to secure facts if necessary.

The decision of the tribunal implicated both sides in technical errors, but it was couched in language that could offend the honor of neither nation. The substance of it was that the German consul should not have given safe conduct to the deserters, but that the French military authorities should have endeavored,

14 Procedings of the American Society of International Law, rgog, 50-5I. 
as far as possible, to obtain possession of the deserters without the use of force, the excessive display of which, on this occasion, was criticised. The deserters, however, were left in possession of the French, the tribunal not passing judgment upon this point, and each governments, according to previous agreement, apologized to the other for its mistakes.

Among the more recent cases taken up and successfully disposed of by the Hague Court have been those submitted by Sweden and Norway, after their separation, relating to a disputed boundary; by the United States and Venezuela in regard to the claims of the Orinoco Steamship Company, and by Great Britain and France in connection with a point of law as to the legality of the surrender of an Indian prisoner, Vinayak Damodar Savarkar, who escaped from British detectives while in their custody on a British steamship in the harbor of Marselles, and was immediately, but informally, returned to them by local police without first being handed over to the chief of the harbor police. The Orinoco Steamship Company case, the only one of these cases to which there is opportunity to refer, except by name, was between the United States and Venezuela. Like the Pious Fund Case, it related to an arbitral award already made, but, in this instance, the valid part of the award was allowed to stand, while the invalid part was tried anew, on its merits. This was pursuant to an agreement by the two governments that the previous question of the validity of the award should first be passed upon by the tribunal, "in view of all the circumstances and under the principles of international law." The ground of invalidity was departure from the terms of the protocol, an essential error, that is, a denial of justice, under which the case was originally submitted by the United States and Venezuela to Dr. Barge, the umpire of the United States and Venezuela Claims Commission of 1903. The amount originally claimed was about $\$ 1,400,000$. The sum granted was $\$ 92,607.52$ against $\$ 28,224.93$ originally allowed by Dr. Barge. The court held itself unable to review on the merits the largest claims involved, but on such claims as were reriewed on the merits, the court allowed about two-thirds of the amount claimed.

"Turning from the financial to the legal aspect of the decision," writes Mr. Dennis, the agent of the United States, "the all-important thing about the decision is that for the first time 
an international award has been annulled by an international tribunal." 15

- These cases show a growing tendency of the governments to refer to the court a variety of difficulties. Some of these had already led to bad feeling and might, without adjustment, have become dangerous irritants between the peoples, represented by the governments, and formed a part of an accumulation of grievances liable to be recalled in a moment of national passion, over some new and unexpected incident. Failure to pay debts, as already seen in the first case of Venezuela, has led to the use of the military arm, but this is not all. The use of the court is not only for the prevention of war, but for the upholding of justice, without which a scheme for the prevention of war might, on some grounds, become open to criticism. The fact that the court secures justice where otherwise justice might be delayed or never realized, with war or without war; this aspect of the Hague peace system, peace with justice, is a virtue that cannot fail to commend it even to believers in war for virtue's sake. This point is more particularly illustrated by the Fisheries Case, which, from its historic nature, deserves more extended consideration.

The settlement by the Hague Court of the North Atlantic fisheries question closed a controversy that had perplexed British and American statesmen, at different times, for seventy years.

By the treaty of peace, $x_{7} 83$, practically all the British coasts of North America were left open to American fishermen to dry fish on, except those of Newfoundland, but Americans were allowed to take fish in all British coastal waters, as had been the custom in colonial days. When, however, at the close of the war of 1812, terms of peace were made at Ghent, the British Government asserted, and the United States commissioners denied, that the war had abrogated the fisheries article of the former treaty, and no mention of the fisheries was made in that treaty. The action of British war vessels led to vehement protests and threats of war. Diplomatic correspondence followed, at the end of which both parties came to an agreement by the treaty of London, I8IS, the first article of which relates to the fisheries. By this treaty, it was agreed that the United States should have perpetual liberty to take fish on certain coasts of Newfoundland and the Magdalen

${ }^{15} 5$ Am. Jour. Int. Law, 54 . 
Islands, and on certain coasts of Labrador, in common with British subjects. The treaty also gave the American fishermen the liberty to dry and cure fish on certain unsettled shores within limits described on the Newfoundland and Labrador coasts, subject to agreement with inhabitants and proprietors whenever, in the future, those shores should be settled. The United States renounced their liberty before enjoyed, or claimed, to take or dry or cure fish within three marine miles of any other of the coasts, bays, creeks, or harbors of his Majesty's Dominions in America, but it was agreed that American fishermen might enter such waters "for the purpose of shelter and repairing damage therein, of purchasing wood, and of obtaining water, and for no other purpose whatever." And it was provided that regulations be made to prevent the abuse of such privileges granted on these, sometimes called the non-treaty, coasts.

If there was a marked difference between the fisheries provisions of the treaty of 1783 and those of 1818 , it was due, in part, to the fact that conditions had changed in the interval, owing to the settlement and growth of the British colonies affected by the treaties, and the value to those colonies of the local fisheries, of which they had begun to make use. The treaty of I8I8 was well calculated to recognize these changes, but, as Mr. Robert Lansing who has written a very able account of the fisheries case, observes, it did not consider future growth. Indeed, had it done so there might never have been a fisheries arbitration. Conditions continued to change, especially in Newfoundland, which in early days was practically a closed country to settlers, but which in late years has been opened up to settlement. Inhabitants of Newfoundland and the Maritime Provinces began to look tpon their enterprising New England rivals with jealous eyes, and, in the case of Newfoundland, with good reason, because the fisheries were their sole dependence, and, in any event, deserved proper protection.

Considerable irritation arose which finally led, on the part of Canada, but more particularly Newfoundland, to the making of rigorous local laws, by which Americans were seriously restricted as to days, seasons, and the manner of taking fish. They were penalized for shipping Newfoundland fishermen, and were made to enter and clear at customs houses, although these houses were at a long distance from the scene of fishing, and although the fishermen were not engaged in trading. American fishermen 
were also compelled to pay light and harbor dues. Similar requirements were made of American fishing vessels resorting to non-treaty coasts for the legitimate purpose of making repairs, seeking shelter, and obtaining wood and water.

Although the irritation of the early days was allayed by the reciprocity treaties of 1854 and $187 \mathrm{I}$, and, although since the failure of the Bayard-Chamberlain treaty of I888 from nonratification by the Senate, peaceful and, to a certain extent, satisfactory relations had been maintained by a system of licenses granted by both Canada and Newfoundland, an oppressive and discriminating statute was made by Newfoundland against American fishermen in 1905. Diplomatic correspondence, between Great Britain and the United States, followed, pending the result of which American fishermen visited Newfoundland coasts under a modus vivendi. War was not threatening, but continuous friction, liable to lead to dangerous trouble, and to cause serious financial loss to the fishing interests of the United States, made a settlement desirab?.

The case was finally referred for settlement to the Hague Court under the present arbitration treaty with Great Britain by special agreement of January 27, I909. Seven questions, prepared in the light of the vexatious differences of the past, were submitted to the tribunal, which in effect, called for a detailed interpretation of the fisheries article of the treaty of $18 \mathrm{r} 8$, which was still in force.

The principal question related to the reasonableness of the fisheries regulations. The United States, conceiving that they enjoyed the liberty of the fisheries in common with British subjects, though under limitations defined by the treaty, believed they should be consulted when regulations were made, and that their concurrence was necessary to the enforcement of the regulations. This question involved the sovereignty of Great Britain and she denied the contention of the United States. The tribunal, on the point of law, decided for Great Britain, and, therefore, technically saved her sovereignty which otherwise would have been impaired, but ruled that the regulations should be reasonable and equitable, and that, in case of disagreement as to their reasonableness or fairness, the points at issue should be referred to a special body of experts consisting of one subject of each party, with a netitral to act as umpire; the procedure to be similar to that provided for in summary cases by the Hague Conference of 
I907. The tribunal decided that the words "inhabitants of the United States" in the treaty of 1818 did not prevent the prosecution of the fishery by the employment of Newfoundland and other foreign fishermen. It decided that American fishing vessels, going to a treaty coast to fish, or to dry and cure fish; or to non-treaty coasts for shelter, repairs, wood, or water, should not be required to enter and clear at customs houses, but recommended that they should report their presence, if convenient means were at hand to do so: namely, a customs house or a customs official who could be reached by telegraph, and declared that light and harbor dues should not be charged unless Newfoundland fishermen were also required to pay them.

The tribunal was asked to pass upon the historic question of the "three mile limit" (question five), but, though it overthrew the contention of the United States, it did so only in a qualified forn. It decided that the word "bays," as used in the treaty of I8I8, meant those bodies of water commonly known and charted as bays at that time, and did not mean bays, six miles wide at the mouth, or jurisdictional bays, as claimed by the Lnited States; and, as international law in I8IS did not definitely fix the point at which a bay terminated and the high seas began, the tribunal laid down no definite rule. It suggested, however, that the principle of the North Sea Convention, that the high sea should terminate and a bay begin where the shores first approach each other within ten miles, should be adopted, but excepted from this recommendation such bays as deeply indented his Majesty's Dominions, and suggested that their limits be arbitrarily defined along the lines of the unratified Bayard-Chamberlain treaty of 1888. Examples of such bays are Chaleur, Placentia, Egemont, and Fortune. Dr. Drago, who in an ably written opinion, dissented from this view, asserted that the ten mile limit should be established as a part of the decision, and not as a recommendation. ${ }^{10}$ Of this question (five), it is felt that the tribunal failed to make a practical solution. A special contention of the government of Newfoundland that the wording of the treaty precluded the American fishermen from entering the bays, creeks, harbors, etc., of Newfoundland on the treaty coasts, as the words "bays, harbors, and creeks" were not expressly used in the treaty in regard to Newfoundland by itself, was denied by the tribunal.

${ }^{10} 4$ Am. Jour. Int. Law, g\&S. 
The effect of this particular decision is of great importance to the winter herring fishing of the United States, which otherwise, under the ingenious restrictive interpretation of Sir Robert Bond, might have been ruined or seriously crippled.

The tribunal decided that the inhabitants of the United States may engage in trade or fishing on the treaty coasts, but may not use both privileges on the same voyage. This decision, however, does not prevent a vessel from going to the treaty coasts for trading purposes, and having finished its business, engaging, under license, in fishing on the homeward voyage.

The decision of the tribunal, on one point of question one, and on question five, denied the contention of the United States, and gave to the government of Great Britain a technical victory, saving its sovereignty; but, on the second contention of question one, and on five other questions, declared a rule in favor of the United States. From an industrial point of view, the United States gained a substantial victory, as the tribunal required that fisheries regulations should, hereafter, be reasonable and fair, and admitted American fishermen to Newfoundland waters from which an attempt was made to debar them. The decision, however, has proved acceptable to both governments and to their peoples. The case will stand with the Genera award in the category of the greatest of international arbitrations.

The fisheries arbitration and the eight arbitrations of the Hague Court, in about one decade of its existence, the use of the international commission of inquiry in dealing with the North Sea incident, and the mediation of President Roosevelt in the war between Russia and Japan, have shown that some features of the Hague peace system have already proved their practical success, and justified belief in the feasibility of the system as a whole.

James L. Tryon. 